\title{
Evaluasi Konservasi Mangrove Berdasarkan Tingkat Partisipasi Masyarakat di Pulau Pramuka, Kepulauan Seribu, Jakarta
}

\author{
[Evaluation of Mangrove Conservation Based on Community Participation in \\ Pramuka Island, Kepulauan Seribu, Jakarta]
}

\section{Laras Ega Pratiwi, Djoko Suprapto, Wiwiet Teguh Taufani}

\author{
Program Studi Manajemen Sumberdaya Perairan, Jurusan Perikanan \\ Fakultas Perikanan dan IImu Kelautan, Universitas Diponegoro \\ Jl. Prof. Soedarto, SH, Tembalang, Semarang, Jawa Tengah - 50275, Telp/Fax. +6224 7474698
}

\begin{abstract}
Abstrak
Pulau Pramuka dijadikan salah satu zona pemukiman taman nasional. Perkembangan pembangunan menyebabkan berkembangnya aktivitas ekonomi, jasa dan pertumbuhan pendudukan yang berdampak pada menyempitnya tutupan lahan ruang terbuka hijau, termasuk kawasan mangrove sehingga dilakukan beberapa upaya konservasi mangrove. Kawasan konservasi ini kemudian dikembangkan menjadi wisata tracking mangrove dengan landasan RPJMD (Rancangan Pembangunan Jangka Menengah Daerah) Jakarta. Tujuan dari penelitian ini adalah mengevaluasi upaya konservasi mangrove berdasarkan tingkat partisipasi masyarakat di Pulau Pramuka. Penelitian ini dilakukan pada bulan Maret 2019. Penelitian ini menggunakan metode deskriptif kuantitatif. Pengolahan data menggunakan SPSS dengan uji regresi korelasi untuk mengetahui hubungan antara upaya konservasi dan partisipasi. Teknik pengumpulan data observasi dan wawancara dengan bantuan kuesioner menggunakan teknik accidental sampling kepada 91 masyarakat, 30 pengunjung dan 9 pengelola. Upaya konservasi yang dilakukan dengan patokan RPJMD Jakarta tahun 2017-2022 perlu dilakukan pembenahan dan peningkatan dibeberapa bagian. Upaya yang dilakukan perlu diimbangi dengan partisipasi karena saling berhubungan. Terdapat hubungan yang lemah antara upaya dan partisipasi oleh masyarakat dengan $r: 0.451$ dengan kontribusi hubungan sebesar $18,7 \%$, sedangkan hubungan yang sangat kuat oleh pengunjung dengan $r$ : 0.874 dengan kontribusi hubungan sebesar $90,5 \%$. Faktor utama yang mempengaruhi partisipasi adalah pengetahuan dan kurangnya pelibatan masyarakat dalam program konservasi, seperti perencanaan dan evaluasi. Tingginya kontribusi pengunjung dalam upaya konservasi dikarenakan program konservasi yang dilaksanakan memiliki target pasar yaitu pengunjung, sehingga partisipasi pengunjung lebih besar dibandingkan partisipasi masyarakat.
\end{abstract}

Kata kunci : mangrove; konservasi; partisipasi; Pulau Pramuka

\section{Abstract}

Pramuka Island is used as one of the national park residential zones. Development has led to the growth of economic activities, services and growth of occupiers that affecting on reduced of the open space, including mangrove areas, thus important to do the mangrove conservation. This conservation area was developed into a mangrove tracking tour based on the RPJMD (regional mid-term development plan) of Jakarta. The purpose of this research is to evaluate mangrove conservation efforts based on the level of community participation on Pramuka Island. This research was conducted in March 2019. This research used a quantitative descriptive method. Data processing uses SPSS with correlation regression test to determine the relationship between conservation efforts and participation. The techniques for collecting observation data and interviews have done with questionnaires used an accidental sampling techniques to 91 communities, 30 visitors and 9 maintainers. The conservation efforts based on the Jakarta RPJMD from 2017-2022 is need to be improved and enhanced in several parts. The efforts made need to be balanced with participation because, it is related. There is a weak relation between effort and participation by the community it is showed from $r$ : 0.451 with a contribution in $18.7 \%$, while a very strong relation by visitors, it is showed $r$ : 0.874 with contribution in $90.5 \%$. The main 
factors influencing participation are knowledge and lack of community involvement in conservation programs, such as planning and evaluation. The high contribution of visitors in conservation efforts due to the conservation program carried out has a target market which is visitors, so that visitor's participation is grater than community participation.

Keywords : conservation; mangrove; participation; Pramuka Island

Penulis Korespondensi

Laras Ega Pratiwi | larasegap29@gmail.com

\section{PENDAHULUAN}

Pemanfaatan mangrove secara berlebih baik langsung maupun tidak langsung menyebabkan menurunnya luasan lahan mangrove. Salah satu contohnya adalah kawasan ekosistem mangrove di Kepulauan Seribu. Hutan mangrove di Kepulauan Seribu tersisa $1.8 \%$ atau sekitar 72 ha dari total luas lahan 4,027 ha. Idealnya $30 \%$ dari 4,027 ha dijadinyan lahan mangrove untuk mencegah abrasi dan menjaga keutuhan ekologi Kepulauan Seribu, jadi setidaknya harus ada 1,300 ha lahan mangrove di seluruh Kepulauan Seribu (Sumarto 2013).

Perkembangan pembangunan di Pulau Pramuka tidak hanya menyebabkan perkembangan aktivitas ekonomi dan jasa, tetapi juga diikuti pertumbuhan penduduk yang pesat sebesar $2.54 \%$ per tahun. Dampak dari pertumbuhan ini adalah tutupan lahan ruang terbuka yang menyempit. Permasalahan di Pulau Pramuka tersebut menjadi alasan dibentuknya kawasan konservasi mangrove yang kemudian dikembangkan menjadi wisata dengan landasan UU No.5 tahun 1990 tentang Konservasi Sumberdaya Alam Hayati dan Ekosistemnya, UU No.26 tahun 2007 tentang Penataan Ruang. Partisipasi masyarakat dalam pelestarian, pengembangan dan konservasi adalah salah satu hal yang penting menurut ketiga landasan tersebut. Evaluasi juga diperlukan agar segala kegiatan dapat berjalan sesuai dengan landasan dan kesalahan dapat segera diperbaiki.

Tujuan penelitian ini adalah sebagai berikut :

1. Mengetahui upaya konservasi mangrove di Pulau Pramuka.

2. Mengetahui partisipasi masyarakat dalam konservasi mangrove.

3. Mengetahui hubungan antara partisipasi masyarakat dengan upaya konservasi mangrove dan pengembangan ekowisata mangrove di Pulau Pramuka.

\section{BAHAN DAN METODE}

Materi dalam penelitian evaluasi konservasi mangrove berdasarkan tingkat partisipasi masyarakat adalah 
Tabel 1. Hasil uji validitas kuesioner masyarakat

\begin{tabular}{cccl}
\hline \multicolumn{1}{l}{ hhitung $_{\text {Sol }}: 0.649$} & \multicolumn{1}{c}{$\mathbf{r}_{\text {tabel }}$} & Keterangan \\
\hline Soal $2: 0.673$ & $>$ & 0.207 & kuesioner valid \\
Soal $3: 0.889$ & $>$ & 0.207 & kuesioner valid \\
Soal $4: 0.534$ & $>$ & 0.207 & kuesioner valid \\
Soal $5: 0.433$ & $>$ & 0.207 & kuesioner valid \\
Soal $6: 0.433$ & $>$ & 0.207 & kuesioner valid \\
Soal $7: 0.533$ & $>$ & 0.207 & kuesioner valid \\
Soal $8: 0.523$ & $>$ & 0.207 & kuesioner valid \\
\hline
\end{tabular}

Tabel 2. Hasil uji realiabilitas kuesioner masyarakat

\begin{tabular}{cc}
\hline Cronbach's Alpha & N of Items \\
\hline 0.779 & 9 \\
\hline
\end{tabular}

program pengelolaan dalam upaya konservasi dan partisipasi masyarakat. Sasaran dari penelitian ini adalah masyarakat, pengunjung dan pengelola konservasi mangrove. Variabel yang diukur adalah partisipasi dan persepsi responden mengenai upaya konservasi oleh pengelola. Variabel partisipasi yang diukur meliputi aksi dalam pelestarian, penyusunan rencana kerja, peran dalam penanaman dan pembibitan serta peran dalam monitoring dan evaluasi, sedangkan variabel persepsi yang diukur adalah pengetahuan mengenai mangrove, penilaian mengenai keadaan mangrove serta pengetahuan mengenai fungsi mangrove. Metode yang digunakan dalam penelitian ini adalah metode deskriptif kuantitatif dengan teknik accidental sampling. Metode evaluasi yang digunakan adalah responsive evaluation model yaitu pendekatan kualitatif-naturalistik yang melukiskan sebuah realitas dari berbagai perspektif orang yang terlibat. Langkah evaluasi meliputi observasi, wawancara, merekam hasil wawancara, mengumpulkan data yang berkaitan, mengecek pengetahuan awal dan mengembangkan desain (Muryadi 2017). Berikut adalah hasil uji validitas dan reliabilitas kuesioner masyarakat yang telah disusun, kemudian diuji menggunakan SPSS.

Berdasarkan hasil uji validitas diatas dapat diketahui bahwa semua item pertanyaan dinyatakan valid. Sedangkan berdasarkan uji reliabilitas diketahui bahwa nilai Cronbach's Alpha sebesar 0.779 , dengan hipotesis jika nilai 
Tabel 3. Hasil uji validitas kuesioner pengunjung

\begin{tabular}{cccc}
\hline \multicolumn{1}{c}{$\mathbf{r}_{\text {hitung }}$} & & \multicolumn{1}{c}{$\mathbf{r}_{\text {tabel }}$} & Keterangan \\
\hline Soal $1: 0.344$ & $>$ & 0.306 & kuesioner valid \\
Soal $2: 0.049$ & $>$ & 0.306 & kuesioner tidak valid \\
Soal $3: 0.339$ & $>$ & 0.306 & kuesioner valid \\
Soal $4: 0.339$ & $>$ & 0.306 & kuesioner valid \\
Soal $5: 0.339$ & $>$ & 0.306 & kuesioner valid \\
Soal $6: 0.365$ & $>$ & 0.306 & kuesioner valid \\
Soal $7: 0.339$ & $>$ & 0.306 & kuesioner valid \\
Soal $8: 1.000$ & $>$ & 0.306 & kuesioner valid \\
\hline
\end{tabular}

Tabel 4. Hasil uji realiabilitas kuesioner pengunjung

\begin{tabular}{cc}
\hline Cronbach's Alpha & N of Items \\
\hline 0.912 & 8 \\
\hline
\end{tabular}

Cronbach's Alpha >0.60 maka kuesioner atau angket dinyatakan reliabel atau konsisten, sedangkan jika nilai Cronbach's Alpha $<0.60$ maka kuesioner atau angket dinyatakan tidak reliabel atau tidak konsisten. Berdasarkan hipotesis tersebut maka dapat disimpulkan bahwa nilai Cronbach's Alpha sebesar $0.779>0.60$ sehingga kuesioner reliabel atau konsisten. Berikut adalah hasil uji validitas dan reliabilitas kuesioner pengunjung yang telah disusun, kemudian diuji menggunakan SPSS.

Berdasarkan hasil uji validitas diatas dapat diketahui bahwa tujuh item pertanyaan dinyatakan valid dan pertanyaan nomor 2 dinyatakan tidak valid. Sedangkan berdasarkan uji reliabilitas diketahui bahwa nilai
Cronbach's Alpha sebesar 0.912, dengan hipotesis yang sama maka kuesiner dinyatakan reliabel atau konsisten.

Metode penentuan jumlah responden dengan menggunakan rumus slovin. Jumlah masyarakat di Pulau Pramuka pada tahun 2018 sebanyak 1,004 jiwa, dikarenakan lebih dari 1,000 maka digunakan derajat eror $10 \%$ diperoleh hasil 91 responden masyarakat sebagai sampelnya (Imron 2017). Sedangkan pengunjung Pulau Pramuka pada tahun 2018 sebanyak 438/minggu, dengan derajat eror $20 \%$ diperoleh hasil 24 responden pengunjung sebagai sampel, nilai ini dibulatkan menjadi 30 karena ukuran sampel yang layak dalam 
Tabel 5. Pelaksanaan program konservasi

\begin{tabular}{|c|c|c|c|c|}
\hline No. & $\begin{array}{l}\text { Landasan } \\
\text { Undang- } \\
\text { Undang } \\
\text { No.5 tahun } \\
1990\end{array}$ & $\begin{array}{l}\text { RPJMD DKI } \\
\text { Jakarta tahun } \\
2017-2022\end{array}$ & Riil Kegiatan & Keterangan \\
\hline \multirow[t]{4}{*}{1.} & $\begin{array}{l}\text { Perlindungan } \\
\text { sistem } \\
\text { penyangga } \\
\text { kehidupan }\end{array}$ & $\begin{array}{l}\text { Pembangunan } \\
\text { signage }\end{array}$ & $\begin{array}{l}\text { Adanya papan informasi } \\
\text { pengetahuan umum } \\
\text { mangrove sekitar kawasan } \\
\text { konservasi }\end{array}$ & $\begin{array}{l}\text { Tidak ada papan } \\
\text { larangan dan } \\
\text { penunjuk arah }\end{array}$ \\
\hline & & $\begin{array}{l}\text { Pembangunan } \\
\text { tanggul }\end{array}$ & $\begin{array}{l}\text { Pembangunan tanggul di } \\
\text { sisi barat }\end{array}$ & $\begin{array}{l}\text { Dibagian Taman } \\
\text { Nasional }\end{array}$ \\
\hline & & $\begin{array}{l}\text { Penanaman dan } \\
\text { rehabilitasi } \\
\text { mangrove }\end{array}$ & $\begin{array}{l}\text { Pembibitan dan } \\
\text { penanaman mangrove, } \\
\text { pembuatan kawasan } \\
\text { konservasi }\end{array}$ & $\begin{array}{l}\text { Hanya terdapat dua } \\
\text { kelompok peduli } \\
\text { lingkungan (Rumah } \\
\text { Hijau dan Pesona } \\
\text { Karang) }\end{array}$ \\
\hline & & $\begin{array}{l}\text { Pengolahan } \\
\text { sampah ramah } \\
\text { lingkungan terpisah } \\
\text { dari pemukiman }\end{array}$ & $\begin{array}{l}\text { Daur ulang sampah } \\
\text { menjadi kerajinan tangan, } \\
\text { pembuatan kompos }\end{array}$ & $\begin{array}{l}\text { Masih ada } \\
\text { pembakaran } \\
\text { sampah }\left(9.52 \mathrm{~m}^{3} /\right. \\
\text { hari) }\end{array}$ \\
\hline \multirow[t]{3}{*}{2.} & $\begin{array}{l}\text { Pengawetan } \\
\text { Keanekaraga } \\
\text { man hayati }\end{array}$ & $\begin{array}{l}\text { Pengembangan } \\
\text { pariwisata berbasis } \\
\text { masyarakat }\end{array}$ & $\begin{array}{l}\text { Pembuatan wisata tracking } \\
\text { mangrove }\end{array}$ & $\begin{array}{l}\text { Sedikit masyarakat } \\
\text { yang ikut andil }\end{array}$ \\
\hline & & $\begin{array}{l}\text { Penjagaan } \\
\text { ekosistem }\end{array}$ & $\begin{array}{l}\text { Monitoring setiap } 2 \text { bulan } \\
\text { sekali }\end{array}$ & $\begin{array}{l}\text { Tidak ada } \\
\text { penjagaan setiap } \\
\text { hari }\end{array}$ \\
\hline & & $\begin{array}{l}\text { Pembangunan } \\
\text { sarana dan } \\
\text { prasarana }\end{array}$ & $\begin{array}{l}\text { Fasilitas tempat sampah, } \\
\text { Tempat Pembuangan } \\
\text { Sampah (TPS) Sementara, } \\
\text { fasilitas toilet di kawasan } \\
\text { konservasi dan tempat } \\
\text { ibadah }\end{array}$ & $\begin{array}{l}\text { TPS belum layak } \\
\text { karena di tengah } \\
\text { pemukiman dan } \\
\text { dekat kawasan } \\
\text { konservasi }\end{array}$ \\
\hline \multirow[t]{2}{*}{3.} & $\begin{array}{l}\text { Pemanfaatan } \\
\text { sumberdaya } \\
\text { alam lestari }\end{array}$ & $\begin{array}{l}\text { Pembangunan } \\
\text { floating deck untuk } \\
\text { menikmati } \\
\text { mangrove }\end{array}$ & $\begin{array}{l}\text { Pembangunan floating } \\
\text { deck di kawasan } \\
\text { konservasi }\end{array}$ & $\begin{array}{l}\text { Pembangunan } \\
\text { belum selesai }\end{array}$ \\
\hline & & $\begin{array}{l}\text { Pengembangan } \\
\text { pariwisata berbasis } \\
\text { masyarakat }\end{array}$ & $\begin{array}{l}\text { Penyuluhan dan } \\
\text { pengajaran mengenai } \\
\text { mangrove kepada siswa } \\
\text { sekolah dasar }\end{array}$ & $\begin{array}{l}\text { Sasaran } \\
\text { pesertanya kurang } \\
\text { luas }\end{array}$ \\
\hline
\end{tabular}

penelitian adalah antara $30-500$ (Sugiyono 2008).

Proses pertama dalam analisis data adalah memberikan skor pada jawaban responden dengan skala Likert.
Data yang telah diperoleh kemudian diolah menggunakan SPSS untuk mengetahui regresi korelasi antara upaya konservasi dengan partisipasi. Hasilnya akan dianalisis dengan model 
Miles dan Huberman, yaitu mereduksi data yang tidak diperlukan kemudian penyajian data secara singkat sebelum ditarik kesimpulan dari penelitian (Janti 2014).

\section{HASIL DAN PEMBAHASAN}

\section{Hasil}

\section{Gambaran Umum Lokasi Penelitian}

Pulau Pramuka merupakan salah satu pulau yang termasuk dalam Kabupaten Administrasi Kepulauan Seribu, yang terletak disebelah utara teluk Jakarta dengan titik koordinat $06^{\circ} 00^{\prime} 40^{\prime \prime}$ dan $05^{\circ} 54^{\prime} 40^{\prime \prime}$ lintang selatan dan 10640'45" dan 10901'19" bujur timur. Luas Pulau Pramuka yang mencapai $16 \mathrm{Ha}$ maka pulau ini diperuntukan sebagai ibukota kabupaten dan zona pemukiman. (Rahardjo 2013). Pulau Pramuka menggalakan konservasi mangrove dan dikembangkan menjadi wisata tracking mangrove sebagai salah satu destinasi wisata dibawah kendali Balai Taman Nasional Kepulauan Seribu (BTNKpS) sesuai dengan Peraturan Menteri Kehutanan Nomor : PM.03/MENHUT-II/2007. Pengelolaan Taman Nasional Kepulauan Seribu dibagi menjadi 3 wilayah Seksi Pengelolaan Taman Nasional (SPTN), yaitu SPTN wilayah I yaitu Pulau Kelapa, SPTN wilayah II yaitu Pulau Harapan dan SPTN wilayah III yaitu Pulau Pramuka.

\section{Rencana Kegiatan Konservasi}

Konservasi sumber daya alam hayati dan ekosistemnya dilakukan melalui beberapa kegiatan berdasarkan Undang-Undang No.5 tahun 1990 pasal

3. Berdasarkan landasan tersebut maka seluruh kegiatan konservasi harus dapat mencakup ketiga yang dimaksud. Kegiatan konservasi ini kemudian dituangkan dalam RPJMD DKI Jakarta tahun 2017-2022 sebagai patokan untuk mencapai tujuan dan mendukung visi misi pemerintah (Farisanto 2015). Berikut adalah tabel program konservasi berdasarkan RPJMD DKI Jakarta tahun 2017-2022 beserta riil kegiatannya di Pulau Pramuka.

Tabel diatas merupakan kegiatan yang mengacu pada pilar konservasi, yang kemudian dituangkan dalam Rencana Pembangunan Jangka Menengah DKI Jakarta. Berdasarkan hasil observasi dan wawancara dapat diketahui bahwa masih terdapat beberapa kegiatan yang belum terlaksana atau belum sesuai dengan tujuannya.

\section{Upaya Konservasi}

Hasil tabel skor didasarkan atas kesediaan berpartisipasi oleh masyarakat dan pengunjung yang di klasifikasi dengan skala Linkert. Hasil tersebut dapat dilihat pada tabel 6 . 
Tabel 6. Modus nilai upaya konservasi

\begin{tabular}{lll}
\hline \multicolumn{1}{c}{ Upaya Konservasi } & Masyarakat & Pengunjung \\
\hline Menyusun rencana kegiatan & 3 & 3 \\
Peran dalam penanaman dan pembibitan & 3 & 4 \\
Peran dalam monitoring dan evaluasi & 2 & 3 \\
Kesediaan dihukum bila dilanggar & 3 & 3 \\
\hline
\end{tabular}

Keterangan :

1 : Tidak mau berperan

2 : Tidak pernah diikutsertakan

3 : Berperan jika ada himbauan

4 : Berperan jika tidak berhalangan

5 : Selalu ikutserta

Tabel 7. Modus nilai tingkat partisipasi responden

\begin{tabular}{lcc}
\hline \multicolumn{1}{c}{ Tingkat Partisipasi } & Masyarakat & Pengunjung \\
\hline Pengetahuan tentang fungsi mangrove & 3 & 3 \\
Mengetahui tentang konservasi & 3 & 3 \\
Keadaan kawasan konservasi mangrove & 3 & 3 \\
Aksi dalam pelestarian mangrove & 3 & 3 \\
\hline
\end{tabular}

Keterangan :

1 : Sangat tidak mengetahui

2 : Tidak tahu

3 : Cukup mengetahui

4 : Mengetahui

5 : Sangat mengetahui

Berdasarkan Tabel 6. nilai modus upaya konservasi dapat terlihat bahwa mayoritas masyarakat dan pengunjung ikut serta dalam upaya konservasi apabila ada himbauan, himbauan dapat langsung dari pemerintah kabupaten setempat atau pihak pengelola Taman Nasional. Mayoritas nilai masyarakat adalah 3, artinya masih kurang kesadaran dari diri sendiri untuk berperan dalam upaya konservasi.

\section{Tingkat Partisipasi}

Tingkat partisipasi terdiri dari pengetahuan tentang fungsi mangrove, persepsi tentang kawasan konservasi dan aksi dalam pelestarian mangrove. Pertanyaan terbagi menjadi 4 dalam skala linkert. Nilai modus dari tingkat partisipasi masyarakat dan pengunjung dapat dilihat pada Tabel 7.

Berdasarkan Tabel 7 dapat diketahui bahwa semua jawaban memiliki nilai modus 3 , dimana jawaban tersebut dalam skala cukup mengetahui. Pengetahuan responden sampai pada 
Tabel 8. Uji korelasi pada responden masyarakat

\begin{tabular}{|c|c|c|c|c|}
\hline & & & Partisipasi & upaya \\
\hline \multirow{6}{*}{ Kendall's tau_b } & \multirow{3}{*}{ partisipasi } & Correlation Coefficient & 1.000 & $.451^{* *}$ \\
\hline & & Sig. (2-tailed) & . & .000 \\
\hline & & $\mathrm{N}$ & 91 & 91 \\
\hline & \multirow{3}{*}{ upaya } & Correlation Coefficient & $.451^{* *}$ & 1.000 \\
\hline & & Sig. (2-tailed) & .000 & . \\
\hline & & $\mathrm{N}$ & 91 & 91 \\
\hline
\end{tabular}

**. Correlation is significant at the 0.01 level (2-tailed).

Tabel 9. Hasil regresi hubungan pada masyarakat

\begin{tabular}{ccccc}
\hline Model & $\mathbf{R}$ & $\mathbf{R}$ Square & Adjusted R Square & Std. Error of the Estimate \\
\hline 1 & $.433^{\mathrm{a}}$ & .187 & .178 & 1.374 \\
\hline
\end{tabular}

a. Predictors: (Constant), partisipasi

taraf mereka dapat menyebutkan 1-2 fungsi mangrove. Responden juga mengetahui tentang adanya kawasan konservasi dimana terdapat peraturan dilarang merusak mangrove dikawasan konservasi, mengetahui keadaan mangrove dan mengetahui apa aksi yang telah dilakukan.

Hubungan Antara Partisipasi dan Upaya Konservasi oleh Masyarakat

Berdasarkan hasil penelitian terhadap responden masyarakat dengan menggunakan perhitungan statistik metode Kendall's tau yang menganalisis hubungan antara partisipasi dan upaya pengelolaan dapat dilihat hasilnya pada Tabel 8.

Berdasarkan Tabel 8 diperoleh bahwa koefisien korelasi partisipasi dengan upaya maupun upaya dengan partisipasi sebesar $r=0.451$ dengan nilai sig 0.000. Hal ini dapat disimpulkan bahwa nilai signifikan sebesar $0.000<$ 0.05 yang berarti terdapat hubungan antara kedua variabel tersebut. Nilai koefisien korelasi sebesar 0.451 berarti hubungan kedua variabel tersebut lemah (0.26-0.50). Berikut adalah hasil regresi dari hubungan korelasi antara partisipasi dan upaya.

Berdasarkan hasil regresi hubungan pada masyarakat pada Tabel 9 diketahui nilai R Square sebesar 0.187 . Nilai ini mengandung arti bahwa pengaruh partisipasi $(\mathrm{X})$ terhadap upaya (Y) adalah sebesar 18.7\% sedangkan $81.3 \%$ dipengaruhi oleh variabel lain. Hal ini diperkuat dengan melihat arah hubungan korelasi, dimana hasil 
Tabel 10. Uji korelasi pada responden pengunjung

\begin{tabular}{|c|c|c|c|c|}
\hline & & & partisipasi & upaya \\
\hline \multirow{6}{*}{$\begin{array}{l}\text { Kendall's } \\
\text { tau_b }\end{array}$} & \multirow{3}{*}{ Partisipasi } & $\begin{array}{l}\text { Correlation } \\
\text { Coefficient }\end{array}$ & 1.000 & $.874^{* *}$ \\
\hline & & Sig. (2-tailed) & . & .000 \\
\hline & & $\mathrm{N}$ & 30 & 30 \\
\hline & \multirow{3}{*}{ Upaya } & $\begin{array}{l}\text { Correlation } \\
\text { Coefficient }\end{array}$ & $.874^{* *}$ & 1.000 \\
\hline & & Sig. (2-tailed) & .000 & \\
\hline & & $\mathrm{N}$ & 30 & 30 \\
\hline
\end{tabular}

${ }^{* *}$. Correlation is significant at the 0.01 level (2-tailed).

Tabel 11. Hasil regresi hubungan pada pengunjung

\begin{tabular}{ccccc}
\hline Model & $\mathbf{R}$ & R Square & Adjusted R Square & Std. Error of the Estimate \\
\hline 1 & $.952^{\mathrm{a}}$ & .905 & .902 & .680 \\
\hline
\end{tabular}

koefisien korelasi bernilai negatif $(-0.451)$ yang artinya variabel bersifat tidak searah, hal ini berarti bahwa menurun atau meningkatnya partisipasi masyarakat tidak akan mengubah upaya konservasi yang dilaksanakan.

Hubungan Antara Partisipasi dan Upaya Konservasi oleh Pengunjung

Berdasarkan hasil penelitian terhadap responden pengunjung dengan menggunakan perhitungan statistik metode Kendall's tau yang menganalisis hubungan antara partisipasi dan upaya pengelolaan dapat dilihat hasilnya pada Tabel 10 berikut :

Berdasarkan Tabel 10 diperoleh bahwa koefisien korelasi partisipasi dengan upaya maupun upaya dengan partisipasi sebesar $r=0.874$ dengan nilai sig 0.000. Hal ini dapat disimpulkan bahwa nilai signifikan sebesar $0.000<$ 0.05 yang berarti terdapat hubungan antara kedua variabel tersebut. Nilai koefisien korelasi sebesar 0.874 berarti hubungan kedua variabel tersebut sangat kuat $(0.76-0.99)$. Berikut adalah hasil regresi dari hubungan korelasi antara partisipasi dan upaya.

Berdasarkan hasil regresi hubungan pada pengunjung pada tabel 11 diketahui nilai $\mathrm{R}$ Square sebesar 0.905. Nilai ini mengandung arti bahwa pengaruh partisipasi $(\mathrm{X})$ terhadap upaya (Y) adalah sebesar $90.5 \%$ sedangkan $9.5 \%$ dipengaruhi oleh variabel lain. Hal ini diperkuat dengan melihat arah hubungan korelasi, dimana hasil koefisien korelasi bernilai positif ( 0.874$)$ 
yang artinya variabel searah, hal ini berarti bahwa menurun atau meningkatnya partisipasi masyarakat akan mengubah upaya konservasi yang dilaksanakan.

\section{Pembahasan}

\section{Evaluasi Upaya Konservasi}

Papan informasi atau signage dalam kawasan konservasi sangat penting berfungsi untuk memberikan arahan dan peringatan terhadap pengunjung, tetapi di kawasan konservasi mangrove Taman Nasional Kepulauan Seribu hanya terdapat 1 papan informasi yang berisi tentang pengetahuan umum mengenai mangrove, tidak terdapat papan peringatan atau peraturan di sekitar kawasan. Pada penelitian Rosita, Marhanah, and Wahadi (2016) menjelaskan bahwa papan informasi, papan penunjuk arah dan papan peringatan termasuk kedalam fasilitas penunjang yang mempengaruhi kepuasan pengunjung dengan koefisien regresi sebesar 0.058 (cukup kuat). Hal ini diperkuat oleh Peraturan Menteri Pariwisata No.3 tahun 2018 bab IV tentang petunjuk operasional pengelolaan dana alokasi khusus fisik bidang pariwisata, dimana pembuatan rambu-rambu petunjuk arah menjadi salah satu dari 14 upaya peningkatan kualitas daya tarik wisata yang dibiayai pembangunannya.

Papan peringatan yang penting pada suatu kawasan wisata perlu diimbangi dengan upaya penjagaan atau pengawasan langsung disekitar lokasi maupun pengawasan berskala (monitoring) serta diadakan evaluasi. Menurut penelitian Way, Wuisang, dan Supardjo (2016) menjelaskan bahwa standar minimal dari kriteria keamanan adalah adanya petugas khusus keamanan, polisi wisata, pegawai pantai, rambu-rambu perhatian dan pengarah wisatawan. Kriteria ini merupakan media pelibatan masyarakat dalam pengembangan kawasan wisata. Pemantauan dan evaluasi sejauh ini hanya dilaksanakan oleh pengelola Taman Nasional Kepulauan Seribu setiap 2 bulan sekali. Tidak ada pelibatan masyarakat atau pemangku kepentingan lain dalam kegiatan ini. Pemantauan dan evaluasi ini penting dilakukan. Hal ini diperkuat oleh hasil penelitian Setyoningsih, Anggoro, dan Purwanti (2015) bahwa pemantauan penting karena berguna untuk mengetahui apakah usaha yang dilakukan berhasil atau tidak, selanjutkan dilakukan evaluasi guna pengambilan keputusan langkah apa yang sebaiknya dilakukan. Pemantauan dan evaluasi merupakan upaya non struktur yang dilakukan dalam hal pengembangan kawasan wisata dan 
pencegahan abrasi, sedangkan upaya struktur yang dilaksanakan adalah penanaman mangrove dan pembuatan tanggul. Menurut hasil penelitian Rahardjo (2013) penanaman mangrove di Pulau Pramuka terhambat oleh faktor lingkungan yaitu ketersediaan area karena ketiadaan endapan lumpur (sedimen) dan baru beberapa tahun belakangan pengelola menemukan metode yang tepat yaitu penanaman secara rumpun.

Permasalahan lain di Pulau Pramuka adalah mengenai sampah yang terbawa arus dan mengotori pesisir pantai. Menurut penelitian Sahwan (2004) sampah tersebut berasal dari Teluk Jakarta, dimana sampah tersebut merupakan akumulasi dari 13 sungai yang bermuara di teluk. Hal ini diperkuat oleh penelitian Suhada dan Almahdy (2017) bahwa sampah perkotaan baru $60 \%$ terkelola dan $20 \%$ terbuang ke sungai, menyumbang 60\%-70\% pencemaran sungai. Pembakaran sampah dilakukan dengan menggunakan incinerator dan pembakaran di lahan terbuka. Pembakaran dengan incinerator berarti incinerator yang digunakan harus memiliki spesifikasi teknis yang optimal sehingga efisien bahan baku, ramah lingkungan dan mudah dioperasikan (Sahwan 2004). Namun incinerator yang digunakan di Pulau Pramuka tidak ramah lingkungan karena partikulat mengganggu masyarakat terlebih lagi lokasi pembakaran di tengah pemukiman. TPS dibagian timur Pulau Pramuka menyebabkan terjadinya pencemaran tanah karena wilayah TPS memiliki alas tanah yang rawan pencemaran (Cahyadi, Hidayat, dan Wulandari 2013). Masyarakat bersama dengan kelompok peduli lingkungan yaitu Rumah Hijau terus berusaha mandaur ulang sampah plastik menjadi kerajinan kemudian dijual dan bahan bangunan, sedangkan sampah rumah tangga diolah menjadi kompos. Kegiatan ini dilakukan sesuai dengan amanat Undang-Undang nomor 18 Tahun 2008 tentang pengelolaan sampah dan Peraturan Pemerintah nomor 81 Tahun 2012 yang mengamanatkan perlunya perubahan paradigma pengelolaan sampah dari paradigma kumpul-angkutbuang menjadi pengelolaan yang bertujuan pengurangan sampah dan penanganan sampah.

Pengembangan wisata berbasis masyarakat mulai diterapkan di Pulau Pramuka, salah satunya dengan pembuatan tracking mangrove. Tujuannya agar lebih banyak manfaat yang dapat diambil, selain dari aspek ekologi, aspek lainnya yaitu sosial ekonomi, misalnya dapat menjadi tujuan wisata yang baru dan membuka lapangan pekerjaan contohnya untuk 
berdagang. Pengembangan ekowisata tracking mangrove diharapkan dapat menyerap banyak tenaga kerja, tetapi sampai saat ini masih sedikit masyarakat yang ikut andil didalamnya, pelibatan masyarakat hanya sebatas mengikuti kegiatan penyuluhan, menyediakan jasa homestay, kios dan warung makan. Hal ini diperkuat oleh pendapat dari Sanjaya (2018), pengembangan pariwisata berbasis masyarakat harus memberdayakan masyarakat setempat dengan harapan pembagian keuntungan dari pariwisata lebih banyak diterima masyarakat. Pengembangan pariwisata berbasis masyarakat yang menjadi tujuan RPJMD diwujudkan dalam riil kegiatan berupa penyuluhan dan pengajaran siswa sekolah dasar terhadap pengetahuan umum mangrove, pembibitan dan penanaman mangrove. Membangun komitmen dan kesadaran dalam pengendalian lingkungan merupakan langkah awal dalam rehabilitasi lingkungan. Pencemaran lingkungan akan terus terjadi bila tidak ada komitmen dan kesadaran. Komitmen tersebut dapat berupa peraturan tertulis dan kesadaran dapat dibangun melalui pendidikan lingkungan (Lumbessy, Rengkung, dan Gosal 2015). Tetapi sasaran pendidikan konservasi ini masih sangat sempit karena hanya anak sekolah dasar dan beberapa ibu rumah tangga yang tergabung dalam Rumah
Hijau. Pentingnya pendidikan konservasi ini perlu diberikan kepada seluruh masyarakat supaya sadar dan memperhatikan lingkungan, mempunyai pengetahuan, sikap, motivasi dan keahlian yang dapat digunakan untuk menanggulangi masalah konservasi. Tidak hanya memberikan ilmu tetapi output yang diharapkan masyarakat mengetahui sendiri keadaan tempat mereka tinggal dan mengetahui cara berpikir, bersikap dan berperilaku dengan baik dan benar (Sari 2013).

\section{Partisipasi Masyarakat dalam}

Nilai modus mengenai partisipasi masyarakat dan pengunjung semua menunjukan tingkat cukup mengetahui. Kriteria cukup mengetahui dijabarkan dengan responden dapat menjelaskan manfaat yang diperoleh, larangan disekitar kawasan konservasi, keadaan kawasan serta aksi dalam konservasi. Masyarakat dan pengunjug cukup mengetahui tentang konservasi ini karena berusaha untuk tetap berpartisipasi dalam setiap kegiatan. Hal ini serupa dengan penelitian Tanjung, Sadono, dan Wibowo (2017) bahwa tingkat partisipasi masyarakat lebih tinggi akibat selalu berusaha untuk ikut serta dan berpartisipasi aktif dalam setiap kegiatan, sehingga cukup mengetahui perkembangan dari program konservasi. Semua pertanyaan memperoleh respon 
cukup mengetahui atau sedang dalam tingkat persepsi. Persepsi dalam kategori sedang adalah apabila masyarakat dan pengunjung telah menyadari bahwa dirinya bergantung hidup pada sumberdaya hayati hutan mangrove tersebut tetapi belum memahami kalau sumberdaya hayati tersebut perlu dikelola secara lestari agar manfaatnya bisa diperoleh secara berkelanjutan, serta pengelolaannya perlu keiikutsertaan semua pihak baik pengelola, masyarakat dan pengunjung (Ngakan et al. 2006).

\section{Upaya Konservasi}

Upaya konservasi yang dilakukan dan dapat diikuti oleh masyarakat ataupun pengunjung, salah satunya adalah menyusun rencana kegiatan. Sebanyak 93\% dari jumlah responden masyarakat bersedia mengikuti penyusunan rencana kegiatan jika ada himbauan, sedangkan 97\% responden pengunjung tidak mau berperan karena tujuan mereka datang ke Pulau Pramuka untuk berlibur atau penelitian. Masyarakat diberi kesempatan ikut serta untuk menyumbangkan inisiatif dan kreatifitasnya. Sumbangan tersebut dapat disampaikan dalam rapat kelompok atau pertemuan,sehigga pengelola wajib menyediakan sarana penyampaiannya (Meray, Tilaar, dan Takumansang 2016). Menurut penelitian
Santoso (2012) bahwa persepsi masyarakat non-PIK (Pantai Indah Kapuk) (yang kurang intensif berinteraksi dengan ekosistem hutan lindung) relatif kurang baik dibandingkan masyarakat yang lebih intensif berinteraksi dengan hutan lindung. Sedangkan persepsi ini yang akan membangun kesadaran diri msyarakat untuk ikut berpartisipasi.

Upaya penanaman dan pembibitan, mayoritas masyarakat bersedia jika ada himbauan dan pengunjung bersedia jika tidak berhalangan, baik ada atau tidak himbauan dari pengelola. Pada bagian peran dalam monitoring dan evaluasi 89\% masyarakat tidak pernah diikutsertakan dan $87 \%$ pengunjung tidak mau berpartisipasi karena merasa bukan lagi tanggungjawab mereka. Hal ini sangat disayangkan karena seharusnya masyarakat dapat diikutsertakan dalam setiap kegiatan pengembangan mulai dari perencanaan hingga evaluasi dalam berbagai bentuk kegiatan. Partisipasi dalam evaluasi dapat diwujudkan dalam bentuk keikutsertaan masyarakat dalam menilai serta mengawasi kegiatan pembangunan serta hasilnya, sedangkan dalam penilaian tidak langsung dapat berupa pemberian kritikan pada pertemuan kelompok, pemberian saran serta protes Nisrina (2018). Ketaatan terhadap peraturan atau hukuman yang ada, masyarakat 
dan pengunjung bersedia berperan jika ada himbauan, oleh karena itu penting pula dilakukan sosialisasi mengenai peraturan daerah maupun peraturan dari balai pengelolaan Taman Nasional yang berlaku terkait konservasi mangrove yang sedang digalakan. Sosialisasi ini sangat penting karena intensitas penyebaran informasi (sosialisasi) Perda mengenai penataan ruang dengan tingkat kualitas yang tinggi akan mempengaruhi tingkat peran serta masyarakat terhadap proses penataan ruang yang dilakukan. Kesadaran ini perlu dibangun dalam masyarakat (Fikriyani 2014).

\section{Hubungan antara Partisipasi dan Upaya Konservasi}

Berdasarkan uji regresi korelasi antara upaya konservasi dengan partisipasi masyarakat diperoleh hasil bahwa terdapat hubungan yang lemah diantara keduanya. Peningkatan upaya konservasi perlu juga didukung dengan peningkatan partisipasi, dimana kesadaran untuk berpartisipasi pada masyarakat masih sangat kurang. Mayoritas masyarakat akan berpartisipasi jika ada himbauan. Hanya beberapa masyarakat yang sadar untuk ikut andil tanpa ada arahan/himbauan. Variasi tingkat partisipasi masyarakat dalam upaya konservasi dipengaruhi oleh perbedaan pengetahuan masyarakat, semakin tinggi tingkat pengetahuan masyarakat tentang pelaksanaan dan manfaat maka akan semakin tinggi tingkat partisipasi masyarakat (Sudarmadji et al. 2011). Hal ini dapat diatasi dengan pemberian pendidikan konservasi atau penyuluhan untuk dapat mengubah persepsi mereka mengenai konservasi mangrove. Persepsi merupakan proses menyadari akan suatu hal, dapat bernilai positif atau negatif sehingga dapat mempengaruhi tingkat partisipasi masyarakat. Tingkat persepsi yang positif menunjukan masyarakat memiliki tanggapan yang baik tentang adanya pelestarian. Persepsi seseorang besar pengaruhnya terhadap wujud hubungan manusia dengan hutan (Damiati, Lumangkun, dan Dirhamsyah 2015). Lemahnya hubungan antara partisipasi dan upaya konservasi ini juga diakibatkan oleh kurangnya program kerja yang melibatkan masyarakat. Mayoritas program diperuntukan bagi pengunjung sekaligus sebagai suatu atraksi yang disuguhkan jika berkunjung ke Pulau Pramuka, sebagai contoh penanaman mangrove dilakukan dengan target pelaksananya adalah pengunjung sebagai salah satu wisata alam dengan konsep pendidikan.

Berdasarkan uji korelasi antara upaya konservasi dan partisipasi terhadap pengunjung diperoleh hasil yang signifikan dimana terdapat hubungan yang sangat kuat diantara 
keduanya. Besarnya pengaruh hubungan antara partisipasi dan upaya pada pengunjung sebesar $90,5 \%$, nilai ini sangat tinggi diakibatkan oleh setiap program konservasi yang dilaksanakan memiliki target operasional yaitu pengunjung. Sehingga kehadiran dan partisipasi pengunjung sangat penting dalam menjalankan program konservasi tersebut.Pengunjung telah sadar akan pentingnya partisipasi guna mendukung upaya yang telah dibuat oleh pengelola salah satunya dengan menjaga kebersihan sekitar kawasan konservasi dan tidak merusak mangrove. Kesadaran ini ditunjang dengan tingkat pendidikan pengunjung yang tinggi dan tingkat pengetahuan yang luas. Tingkat pendidikan yang dimaksud adalah jenjang pendidikan formal yang diikuti responden. Pentingnya pendidikan formal responden agar dapat mengukur pengetahuan dalam memahami aspek konservasi sumberdaya alam. Semakin lama menjalani pendidikan formal maka kecenderungannya akan dianggap memiliki wawasan dan pengetahuan yang akan berkorelasi positif terhadap partisipasi dan respon terhadap suatu hal yang terjadi disekitarnya (Lestari, Agussabti, dan Alibasyah 2014).

\section{SIMPULAN}

Berdasarkan hasil penelitian yang telah dilakukan dapat diperoleh kesimpulan sebagai berikut :

1. Upaya konservasi di Pulau Pramuka telah berjalan sebagaimana yang dimaksud dalam Rancangan Pembangunan Jangka Menengah Daerah Jakarta tahun 2017-2022 dengan landasan Undang- Undang No.5 tahun 1990, Undang-Undang No.41 tahun 1999 dan Peraturan Pemerintah No.68 tahun 1998.

2. Partisipasi masyarakat dalam upaya konservasi mangrove rendah jika dibandingkan dengan partisipasi pengunjung.

3. Hubungan antara upaya konservasi dan partisipasi masyarakat lemah dengan kontribusi hubungan sebesar $18.7 \%$ dibandingkan dengan pengunjung yang tingkat hubungannya sangat kuat dengan kontribusi hubungan sebesar $90.5 \%$.

\section{PERSANTUNAN}

Penulis menyampaikan rasa terimakasih kepada:

1. Prof. Dr. Ir. Djoko Suprapto, DEA selaku pembimbing utama yang telah banyak memberikan perhatian dan bimbingan kepada penulis dalam penulisan naskah ini;

2. Bapak Wiwiet Teguh T.,S.Pi.,M.Si selaku dosen pembimbing anggota 
atas bimbingan kepada penulis dalam penulisan naskah ini;

3. Seluruh dosen Program Studi Manajemen Sumberdaya Perairan yang telah memberikan ilmu dan bantuan yang bermanfaat selama masa perkuliahan; dan

4. Semua pihak yang telah membantu dalam penyusunan naskah ini.

\section{DAFTAR PUSTAKA}

Cahyadi, Ahmad, Wahyu Hidayat, dan Wulandari Wulandari. 2013. "Adaptasi Masyarakat terhadap Keterbatasan Sumberdaya Air di Pulau Pramuka, Kepulauan Seribu, DKI Jakarta." Jurnal Penelitian Kesejahteraan Sosial 12(2):20714.

Damiati, Veronika, Augustine Lumangkun, dan M. Dirhamsyah. 2015. "Partisipasi masyarakat dalam melestarikan kawasan hutan lindung gunung buduk sebagai sumber air bersih di Desa Idas Kecamatan Noyan Kabupaten Sanggau." Jurnal Hutan Lestari $3(1)$.

Farisanto, Dhani. 2015. "Evaluasi Program Konservasi Guna Melestarikan Kelangsungan Ekologi Di Taman Tegallega." Jurnal Manajemen Resort dan Leisure 12(2).
Fikriyani, Mutia. 2014. "Evaluasi program rehabilitasi mangrove di pesisir desa Bedono Kecamatan Sayung Kabupaten Demak." Ruang 2(1):81-90.

Imron, Hasyim Ali. 2017. "Peran Sampling dan Distibusi Data dalam Penelitian Komunikasi Pendekatan Kuantitatif." Jurnal Studi Komunikasi dan Media 21(1):11126.

Janti, Suhar. 2014. "Analisis validitas dan reliabilitas dengan skala likert terhadap pengembangan si/ti dalam penentuan pengambilan keputusan penerapan strategic planning pada industri garmen." Hal. 155-60 in Prosiding Seminar Nasional Aplikasi Sains \& Teknologi (SNAST). Vol. 15.

Lestari, Titit, Agussabti Agussabti, dan M. Rusli Alibasyah. 2014. "Partisipasi Masyarakat Adat dalam Konservasi Sumberdaya Hutan di Kecamatan Kota Jantho Kabupaten Aceh Besar." Jurnal Manajemen Sumberdaya Lahan 3(2):506-16. 
Lumbessy, Henriyani, Joseph Rengkung, dan Pierre H. Gosal. 2015. "Strategi Konservasi Ekosistem Mangrove Desa Mangega dan Desa Bajo Sebagai Destinasi Ekowisata di Kabupaten Kepulauan Sula." SPASIAL 2(3):192-200.

Meray, Josie Geraldy, Sonny Tilaar, dan

Esli D. Takumansang. 2016.

"Partisipasi Masyarakat terhadap Pengembangan Pariwisata Pantai Mahembang Kecamatan Kakas." SPASIAL 3(3):47-55.

Muryadi, Agustanico Dwi. 2017. "Model evaluasi program dalam penelitian evaluasi." JURNAL ILMIAH PENJAS (Penelitian, Pendidikan dan Pengajaran) 3(1).

Ngakan, P. O., H. Komarudin, A. Achmad, dan Tako Wahyudi. 2006. Ketergantungan, persepsi dan partisipasi masyarakat terhadap sumberdaya hayati hutan: studi kasus di dusun Pampli kabupaten Luwu utara, Sulawesi selatan. Vol.

8. Bogor (ID): CIFOR.

Nisrina, Ariz. 2018. "Partisipasi Masyarakat Dalam Pembangunan dan Pengembangan Objek Wisata DAM Margotirto di Desa Gisting Bawah Kecamatan Gisting Kabupaten Tanggamus." Universitas Lampung.
Rahardjo, Parino. 2013. "Pendekatan Ekosistem Untuk Mitigasi Akibat Perubahan Iklim Pada Pulau Kecil (Pulau Pramuka Kepulauan Seribu)." in Penataan Ruang Berkearifan Lokal dalam Pembangunan Berkelanjutan. Denpasar (ID): Universitas Hindu Indonesia.

Rosita, Rosita, Sri Marhanah, dan Woro Hanoum Wahadi. 2016. "Pengaruh Fasilitas Wisata Dan Kualitas Pelayanan Terhadap Kepuasan Pengunjung Di Taman Margasatwa Ragunan Jakarta." Jurnal Manajemen Resort dan Leisure 13(1).

Sahwan, Firman Laili. 2004. "Strategi pengelolaan sampah di kawasan Kepulauan Seribu." Jurnal Teknologi Lingkungan 5(1).

Sanjaya, Rindo Bagus. 2018. "Strategi Pengembangan Pariwisata Berbasis Masyarakat di Desa Kemetul, Kabupaten Semarang." Jurnal Master Pariwisata Universitas Kristen Satya Wacana $5(1)$.

Santoso, N. 2012. "Arahan kebijakan dan strategi pengelolaan kawasan mangrove berkelanjutan di Muara Angke Daerah Khusus Ibukota Jakarta.[Disertasi]." Bogor (ID): Institut Pertanian Bogor. 
Sari, Dwi Meylinda. 2013. "Evaluasi Program Pendidikan Konservasi Pada Masyarakat Sekitar Taman Nasional Gunung Gede Pangrango." Institut Pertanian Bogor.

Setyoningsih, Dwi, Sutrisno Anggoro, dan Frida Purwanti. 2015. "Evaluasi Upaya Konservasi Mangrove Berdasarkan Tingkat Partisipasi Masyarakat Di Desa Timbul Sloko, Sayung, Demak." Journal of Management of Aquatic Resources 4(3):214-21.

Sudarmadji, Sudarmadji, Slamet Suprayogi, M. Widyastuti, dan Rika Harini. 2011. "Konservasi Mata Air Berbasis Masyarakat di Unit Fisiografi Pegunungan Baturagung, Ledok Wonosari dan Perbukitan Karst Gunung Sewu, Kabupaten Gunungkidul." Jurnal Teknosains 1(1).

Sugiyono. 2008. Statistika untuk Penelitian. Bandung (ID): Alfabeta.
Suhada, Resa Taruna, dan Indra Almahdy. 2017. "Analisis Potensi Sampah Sebagai Sumber Energi Pembangkit Listrik Tenaga Sampah dan Produk Kreatif Untuk Mendukung Pariwisata (Studi Kasus di Kepulauan Seribu)." Jurnal PASTI 11(3).

Sumarto. 2013. Hutan Mangrove Pulau Seribu. Jakarta (ID): Balai Taman Nasional Laut Kepualauan Seribu. Tanjung, Nala Sari, Dwi Sadono, dan Cahyono Tri Wibowo. 2017. "Tingkat partisipasi masyarakat dalam pengelolaan Hutan Nagari di Sumatera Barat." Jurnal Penyuluhan 13(1):14-30.

Way, Irma Herlina, Cynthia E. V Wuisang, dan Suryadi Supardjo. 2016. "Analisis Kebutuhan Sarana dan Prasarana Pariwisata di Danau Uter Kecamatan Aitinyo Kabupaten Maybrat Propinsi Papua Barat." SPASIAL 3(3):27-37. 